R. DEGRYSE

\author{
Het artikel 11 van de \\ Nieuwpoortse keure (1163)
}

Overdruk uit Handelingen van het Genootschap "Société d'Emulation" te Brugge, deel XCVIII (1961).

DRUKKERIJ DEWILDE

HANDZAME 


\section{Het artikel 11 van de Nieuwpoortse keure (1163)}

Artikel 11 van de Nieuwpoortse keure van 1163 luidt : "post diem Sancti Martini precipiet iusticarius opidanis, si voluerit placitare (diebus) tribus" (1).

Met welke soort rechtszitting hebben we hier te doen? Moet men in het Nieuwpoortse, placitum "van na Sint-Maartensdag een jaarlijkse "dorghenga " of betichtingsprocedure (2) zien, dan wel een van de drie in Veurne-Ambacht gebruikelijke "placita generalia" of "ghemeene ghedinghen ", of gold het hier slechts een gewoon geding, welke, wegens bijzondere omstandigheden, slechts na 11 november (Sint-Maartensdag) kon plaatsgrijpen? Wat vooral de aandacht trekt, is de datum. Artikel 11 moet op een rechtelijke waarborg neergekomen zijn. Vergeten we niet, dat zowel de vissers, als de andere zeelieden Sint-Maartensdag als de einddatum van de scheepvaart beschouwden. Van die dag af gingen de vaartuigen op , winterzate "; na die dag werden alle zaken onder de zeevaarders geregeld. De Nieuwpoortse "justiciarius" of officier van justitie, die als voorzitter van de plaatselijke schepenbank optrad, had als plicht de bevolking te verwittigen, indien hij gedurende drie dagen na Sint-Maartensdag recht wou laten spreken. Deze verwittiging moest op 12 november, de 'dag na Sint-Maartensdag, plaatsgrijpen.

Dat met de Nieuwpoortse "placita " van na 11 november een of, zoals de keure het zegt, drie gewone zittingen bedoeld werden, blijkt uit de zeemansgewoonten op dat stuk. Aan de kust mocht inderdaad tijdens de haring-

(1) L. Gilliodts-Van Severen, Coutumes des pars et comté de Flandre. Quartier de Furnes. V; Coutumes de la ville et du port de Nieuport. Brussel, 1901, blz. 143, art. 11. Het woord, diebus" is in de keure tussen de lijnen geschreven.

(2) R. C. Van Caenegem, Geschiedenis van het strafprocesrecht in Vlaanderen van de Kle tot de XIV de eeww (Kon. VI. Ac.). Brussel, 1954, blz. 39, noot 4; 44, noot 2; 98, noot 11; 100 , noot 3 . 
vangst, welke ieder jaar tot in november duurde (3), geen recht gesproken worden over degenen, die op zee waren (4). Wie gedurende deze periode gevangen gezet werd - en dit gold ook voor vreemdelingen - moest tot Sint-Maartensdag in vrijheid worden gesteld (5).

Wanneer greep dan het geding, waarbij zeelieden of vissers betrokken waren, voor de schepenen plaats? Daarvoor vinden we o.a. , binnen 8 daghen " na de ", upset van den harincreyse" d.i. einde november of begin december (6). Inderdaad zien we de Nieuwpoortse wethouders de "eerste dinghedach naer de harinctijd " alsdan met een drinkgelag inzetten (7).

(3) ", Tempus allecium durat octo diebus post festum beati Martini hyemalis...". L. Gilliodts-Van Severen, Coutumes de... Nieuport, a.w., blz. 158, nr X. Oorkonde van mei 1247 : regeling van de heffing van het haringtiend door de Nieuwpoortse schepenen.

(4) " et ou temps de haringuoisons l'en ne porra faire nulle loy sur ceux qui seront aus harens". L. Gilliodts-Van Severen, Inv. des arch. de la ville de Bruges. Brugge, 1871-'78, dl. II, blz. 450-453. Charter van 1324, verleend aan het Brugse Vrije.

(5) "Item, van 9 Inghelschen, die hier ghevanghen lagen, dewelke mijnhere de souvrain zoude hebben ghedaen justicieren, ende omme dat voor eene haringtijd was ende onze poorters ende ghebueren daervoor tland varen moeten, zo baadden de goede lieden van der wet, dat mense van der justice verdraghen willen tote Zinte Maertinsmesse, twelke gheconsenteerd was...". Brussel. Alg. Rijksarchief. Rekenkamer, nr 36717, Stadsrekening van Nieuwpoort van 1413. Zelfde rekening te Nieuwpoort. Oud archief, nr 3507.

(6) , de voornoemde heeschere toghende ende zegghende hoedat de verweerder na Sinte Fransoisdaghe laestleden anno 1500 hem heeschere zine netten ghecorve hadde, begheerende van dien te doen blijcken ende derof de restitucie, de verweerder kennende wel dat hij eene persoon ghecorven hadde, maer ignioreerde wien. Ende naer dallegacie van partien ende overeendraghene van hem beede, so waren de zaken ghecontinueert tot huerlieder upset van den harincreyse binnen 8 daghen dernaer ende den verweerder ontsleghen van vanghenerse, mids stellende goet souffissant zekere te compareerne...". Nieuwpoort. Oud archief, $\mathrm{nr} 72$. Bouc van den acten, fol. 58, Geding voor de Nieuwpoortse , camere" tussen Jan Meynen, stuurman van Duinkerke, , heesscher", en Michiel Gheerare, stuurman van Nieuwpoort, ", verweerder". Beslissing geacteert op 7 augustus 1501. Zie ook ibidem fol. 69 voor de verdere afhandeling van het proces, acte van 11 december 1501 .

(7) , den 4den van decembre, eerste dinghedach naer de harinctijd ende aldoe bij mineheren de bailliu ende de wet verteert upt ghiselhuus...". Brussel. Alg. Rijksarchief. Rekenkamer, nr. 36732. Stadsrekening van Nieuwpoort van 1428. Zelfde rekening te Nieuwpoort. Oud archief, nr 3522. 
Het Nieuwpoortse geding is dus niet met een jaarlijkse "veritas libera" of "dorghenga " te vereenzelvigen. Deze greep overigens te Nieuwpoort niet in november of december, maar tijdens het voorjaar plaats (8). Artikel 11 van de Nieuwpoortse keure slaat dus doodgewoon op een rechtszitting na de haringtijd, waarop de vissers en andere zeelieden konden aanwezig zijn, indien ze in een proces betrokken waren geworden.

R. DEGRYSE 